\title{
Warm-up aktivity při výuce češtiny pro cizince na lékařských fakultách
}

\author{
Iveta Čermáková
}

\begin{abstract}
Abstrakt: Vzhledem k specifické povaze motivace cizojazyčných studentů medicíny při výuce češtiny je nezbytné účelně pracovat s warm-up aktivitami a dalšími postupy, které mohou kompenzovat absenci některých motivačních rysů. Příspěvek představuje konkrétní návrhy, jak s těmito aktivitami pracovat, a upozorňuje na nebezpečí, na která může učitel narazit. Tato rizika vyplývají z odlišného kulturního, vzdělávacího, sociálního a náboženského kontextu, ve kterém podstatná část studentů vyrostla. Příspěvek vycházející z autorčiny letité zkušenosti s výukou ukazuje, jak se zmíněným rizikům vyhnout a jak využít warm-up aktivity smysluplným a účelným způsobem.
\end{abstract}

Klíčová slova: warm-up aktivity, motivace, výuka češtiny pro cizince, multikulturní skupiny

Abstract: With regards to specific motivation of foreign students studying at Czech medical faculties, it is useful to work with various activities that make lessons more attractive. Warmup activities can be incorporated into Czech classes to compensate for the lack of students' motivation to learn the Czech language. The paper presents particular suggestions on how to incorporate these activities into language courses and draws attention to the risks the teacher may face. These risks are associated with different cultural, educational, religious, and social background of students. Based on the author's experience, the paper shows how to avoid these risks and to benefit from warm-up activities in a meaningful and effective way.

Key words: warm-up activities, motivation, Czech for medical students, multicultural groups

\section{1 Úvod}

Obecným rysem vývoje didaktických metod výuky cizích jazyků je odklon od tradičních postupů, založených na konzervativně pojaté překladatelsko-gramatické metodě, obohacené víceméně nahodile o prvky metod dalších, k postupům komunikativnějším. Zaměření na komunikativnost je často spjato s požadavkem na zábavnost vyučování, a to především ze strany studentů. Konkrétním dílčím nástrojem, jak těmto tendencím vyhovět, je práce s tzv. warm-up aktivitami. Cílem tohoto textu je posoudit, do jaké míry je možné a účelné s těmito aktivitami pracovat v prostředí, které je v dvojím smyslu specifické, totiž při výuce češtiny pro cizince na lékařských fakultách. Ona dvojí specifičnost spočívá jednak v tom, že jde o univerzitní prostředí, kde jsou studenty intelektuálně i osobnostně vyspělí jedinci, kteří požadují, aby výuka jazyka zapadala do celkového rázu studia na vysoké škole, a jednak v tom, že motivace těchto studentů je zcela specifická. 


\section{Warm-up aktivity}

Úvodem je pochopitelně nutné definovat, co jsou to warm-up aktivity. Jde o termín velmi užívaný a velmi módní, jak ostatně potvrdí i prostý pohled na internet, nabízející velké množství konkrétních aktivit (je ale potřeba upozornit, že termín je využíván i mimo didaktiku). Podíváme-li se ale na odborné, didakticky zaměřené texty nebo i na spíše populárnější internetové stránky, zjistíme, že se pod warm-up aktivity zařazují činnosti velmi různorodé. Analyzujeme-li tyto různorodé př́stupy, vidíme, že obecně se tyto aktivity spojují se čtyřmi základními cíli, které ale nemusí být u konkrétní aktivity př́tomné všechny:

1. jak už název naznačuje, tyto aktivity by měly studenty „zahřát“, tj. rychle a účinně je uvést do „provozní" teploty, rychle je rozmluvit, „dostat" do jazyka;

2. někdy se ztotožňují s tzv. ice-breakers, tj. připisuje se jim cíl prolomit ledy - předpokládá se, že student pocit’uje nechut' nebo obavu začít mluvit nebo podílet se aktivně na hodině; tento cíl se může částečně překrývat s cílem předchozím, ale není nutně identický (tématu ice-breakers je věnována velká pozornost $\mathrm{v}$ didaktice angličtiny jako cizího jazyka, v české, srov. též Betáková, Homolová \& Štulrajterová, 2017, ale především v té anglofonní, srov. Cullen, 1998; v posledních letech např vznikla celá řada studií, které popisují nutnost užívání ice-breakers při výuce studentů pocházejících z velmi chudých, zaostalých poměrů, srov. např Marneni, Kubar Bondeni \& Bukya, 2017); z metodologického hlediska je důležité, že přestože je třeba mezi warm-up aktivitami a ice-breakers rozlišovat, protože u pravých ice-breakers se u studenta předpokládá existence jistého mentálního bloku, který je třeba překonat, velká část odborných zdrojů mezi oběma termíny nerozlišuje;

3. řadí se sem i aktivity, kterými učitel reaguje na hrozící nebo reálný pokles pozornosti a zájmu studentů uprostřed hodiny a které mají za cíl pozornost obnovit;

4. z povahy věci se předpokládá, že rychlé přilákání pozornosti studenta $\mathrm{k}$ tématu a jeho rychlé zapojení by mělo být přitažlivé, „zábavné“, proto většina autorů předpokládá, že tyto aktivity by měly pobavit.

$\mathrm{V}$ různých zdrojích nacházíme ještě další př́ívlastky, které se $\mathrm{k}$ těmto aktivitám připojují (např. odrážejí už konkrétní metodu či postup, který se při nich aplikuje, nebo místo ve struktuře hodiny, jako např. tzv. pre-reading activities, pre-listening activities), ale o žádných z nich nemůžeme dle našeho názoru tvrdit, že by patřily $\mathrm{k}$ definičním charakteristikám warm-up aktivit (a to nemluvíme o př́ívlastcích nevhodných, jako je např. označování těchto aktivit spojením drilovací aktivity, jak tomu občas je).

Ze stručného soupisu vlastností aktivit, kterými se budeme zabývat, vyplývá, že budou jen obtížně jednoznačně spojitelné s jednou konkrétní výukovou metodou 
či formou, tak jak se objevují v moderních typologiích těchto metod, přihlížejících k nejrůznějším hlediskům (Maňák \& Švec, 1993; Červenková, 2013 a další). V souladu s těmito autory bychom námi zkoumané aktivity mohli zařadit např. k metodám motivačním (tj. jedné $\mathrm{z}$ variant metod $\mathrm{z}$ hlediska fáze výuky u Maňáka, 1990) nebo k brainstormingu, tj. jedné z komplexních výukových metod (např. u Maňáka \& Švece, 2003). Totožnost těchto termínů ale není úplná, proto asi nejvhodnějším synonymem (či lépe řečeno hyperonymem) jsou aktivizující (např̀ u Jankovcové, Průchy \& Koudely, 1988) nebo aktivizační metody (Kotrba \& Lacina, 2011). Jinými slovy, warm-up aktivity patř́ do této skupiny, ale ne každá aktivizační metoda je warm-up aktivitou. Warm-up aktivity jsou navíc samy o sobě komplexním označením: jak vyplyne $\mathrm{z}$ jejich popisu v následujícím textu, mohou vykazovat rysy diskuse jako významné aktivizující výukové metody, mohou být druhem didaktické hry, mohou být kvízem atd. (podrobněji k těmto termínům např. Červenková, 2013). A jsou samozřejmě i hrou pro osvojování jazykových a komunikativních dovedností (Petty, 2013).

\subsection{Typologie warm-up aktivit}

Základní typologie zkoumaných aktivit souvisí s cíli, o kterých už byla řeč: odráží zařazení těchto aktivit do rámce hodiny a jejich funkci. Rozlišují se:

\section{Aktivity na začátku hodiny}

Tyto aktivity jsou pochopitelně spjaté především s prvními dvěma cíli, o kterých byla řeč $\mathrm{v}$ oddíle 2 , totiž se snahou "dostat" studenty na začátku hodiny do jazyka a „zahřát" je, a též s funkcí ice-breakers.

2. Aktivity uprostřed hodiny či na jejím konci

Tento typ aktivit takřka vždy souvisí s „oživením“ hodiny, jde o reakci na klesající pozornost, příp. o činnost, která má odlehčit situaci např. po obtížné pasáži hodiny (výklad obtížného gramatického jevu, obtížné cvičení či procvičování apod.).

\subsection{Warm-up aktivity a motivace}

Z povahy warm-up aktivit vyplývá jejich zásadní souvislost s motivací. Jak víme, motivace, a to jak vnitřní, tak i vnější, je naprosto klíčovým faktorem jakékoli úspěšné výuky (srov. k tomu např. Čapek, 2015; Fontana, 2014; nebo Lokšová \& Lokša, 1999). Warm-up aktivity v jazykových hodinách vlastně přímo s motivací pracují, a to ve dvou perspektivách. $\mathrm{V}$ té dlouhodobé přispívají $\mathrm{k}$ obecnému zájmu studenta studovat jazyk, $\mathrm{v}$ té krátkodobé - totiž v rámci konkrétní hodiny - okamžitou motivaci bud' „startují", nebo reagují na její pokles. Vzhledem k tomu, že warm-up aktivity obvykle nejsou učitelem nijak vnějškově hodnoceny - jejich cíl je jiný -, pracujeme při nich takřka výhradně s motivací vnitřní: snažíme se ve 
studentovi stále obnovovat přesvědčení, že studium jazyka má pro něj smysl, že mu bude přinášet radost, uspokojení a vnitřní užitek.

\section{Warm-up aktivity a specifičnost výuky češtiny na lékařských fakultách}

Konfrontujeme-li výše uvedené vlastnosti a cíle warm-up s rámcem, ve kterém probíhá výuka češtiny cizinců na lékařských fakultách, nalezneme celou řadu aspektů, které užívání warm-up aktivit znesnadňují nebo které přinejmenším vyžadují specifický přístup učitele.

\subsection{Warm-up aktivity a univerzitní prostředí}

Nejmenším problémem je nepochybně odlišnost univerzitního prostředí od klimatu nižších typů škol (srov. Rohlíková \& Vejvodová, 2012). Na základě našich zkušeností můžeme odmítnout občasné názory, že i výuka jazyků na univerzitě by měla mít seriózní, konzervativní podobu, že studenti očekávají tradiční přístupy. Minimálně na našem pracovišti to neplatí - a je snadné didakticky zdůvodnit proč: naším cílem studenty naučit co nejlépe česky a všechny činnosti, které $\mathrm{k}$ tomu vedou, jsou oprávněné. Dokonce lze konstatovat, že studenti u warm-up aktivit, o kterých bude řeč dále, naopak oceňují jejich naprostou odlišnost od všech studijních činností, kterými se na univerzitě zabývají.

\subsection{Warm-up aktivity a motivace studentů}

Obrovským problémem naopak je motivace. Lze konstatovat, že u většiny zahraničních studentů lékařských fakult dominuje v hodinách češtiny jednoznačně motivace vnější, tj. snaha dostát vnějším požadavkům, které jsou na ně kladeny, totiž absolvovat potřebné atestace bez většího úsilí. Vnitřní motivace u některých z nich dokonce chybí takřka úplně, přinejmenším ta dlouhodobá: zkrátka takřka nepocit'ují potřebu naučit se komunikovat česky, nevidí v tom pro sebe do budoucna perspektivu (předmětem jejich hlavního studijního úsilí jsou pochopitelně odborné lékařské předměty).

U části z nich dochází k pozitivní změně ve vyšších ročnících: jejich vnitřní motivace stoupá, nebot' začínají praktikovat v nemocnici a je po nich vyžadována komunikace s českým pacientem. Práce se studenty ve vyšších ročnících, na naší fakultě konkrétně ve výuce volitelného kursu češtiny ve čtvrtém ročníku, je proto v jistém smyslu snazší a i vyučujícímu přináší větší satisfakci. Vysvětlení zdrojů této motivace je komplikované - takřka žádný student nespojuje svou profesní budoucnost s působením v České republice, nemohou mít tedy pocit, že zlepšováním češtiny vylepšují svou pracovní kompetenci a vyhlídky do budoucnosti. Zdrojem vyšší motivace je pravděpodobně uspokojení z toho, že čeština je prostředníkem 
jejich úspěšného lékařského zákroku v nemocnici (resp. úspěšného kontaktu s pacientem), příp. vědomí, že komunikace s pacientem je zásadní součástí lékařské profese.

Jak s takovouto motivací studentů souvisejí warm-up aktivity?

Jak ještě ukážeme dále, warm-up aktivity jsou dle našeho soudu velmi důležitým prostředkem, jak se pokusit zvýšit dlouhodobou i okamžitou, krátkodobou motivaci zahraničních studentů ke studiu češtiny.

U té dlouhodobé může vhodně zvolená warm-up aktivita přispět $\mathrm{k}$ lepšímu pochopení českého prostředí, zdejších zvyků a rysů každodenního života: naše zkušenost ukazuje, že čím více se student sžije s českým prostředím, tím lépe chápe důležitost češtiny a jeho připravenost se ji učit stoupne (tím ale rozhodně nechceme ř́ci, že jde změnu radikální, to by neodpovídalo realitě: je to spíš metoda postupných kroků, které zlepšují situaci).

U krátkodobé motivace během hodiny je role warm-up aktivit zásadní: lze říci, že zejména u některých studentů je to vlastně jediný způsob, jak je opravdu vtáhnout do hodiny a dosáhnout alespoň částečně stanovených cílů (tato formulace zní možná pesimisticky, ale odráží dle našeho soudu realitu).

\subsection{Warm-up aktivity a kulturně-národnostní různorodost studentů}

Specifickým aspektem, který musí brát učitel češtiny na lékařských fakultách v úvahu, je kulturní a národnostní různorodost studentů. Ta ovlivňuje celou řadu rysů procesu výuky:

1. Studenti přicházejí z odlišných vzdělávacích systémů a jsou zvyklí na různé podoby výuky jazyka. Různorodost těchto systémů se odráží i v jejich znalosti angličtiny jako základního komunikačního nástroje a v obecné schopnosti učit se cizí jazyk.

2. Zkušenost ukazuje, že ochota učit se cizí jazyk je různá u studentů různých zemí také $\mathrm{v}$ závislosti na tom, jak rozšriřený je jejich rodný jazyk. Obecně platí, že u mluvčích menších jazyků je připravenost učit se cizímu jazyku větší.

3. Specifickým aspektem, který př́mo ovlivňuje volbu a podobu warm-up aktivit, je kulturní a náboženské zázemí studentů. Učitel musí přihlížet ke struktuře dané skupiny a zvažovat vhodnost zařazení aktivit, které jsou spjaté např. s podobou českých svátků (Vánoce, Velikonoce) nebo konkrétních českých tradic a obyčejů. 


\section{Warm-up aktivity ve výuce češtiny na 3. LF UK v Praze}

Hlavním cílem našich výukových hodin je komunikace s českým pacientem a tomuto cíli je pochopitelně přizpůsoben obsah i forma výuky. Na takto malém prostoru není čas na detailní popis poměru jednotlivých obsahových složek hodiny ani na ucelený popis naší metody, a tak jen uvedu, že komunikační aspekt se snažíme zdůrazňovat co nejvíce, a proto máme neustále na paměti, aby studenti mluvili co nejvíce, ideálně od samého počátku vyučovací hodiny - účelným nástrojem mohou být právě warm-up aktivity.

\subsection{Warm-up aktivity na začátku hodiny}

Takto pojaté warm-up aktivity jsou chápány jako „zahřívací“ a umíst’ujeme je na úplný začátek hodiny, tj. nic jim nepředchází. Slouží jako nástroj k rozmluvení studentů a vlastně též jako příprava na další průběh hodiny - je proto důležité, aby jejich propojení s dalším průběhem hodiny bylo organické, nenahodilé, jen tak mohou být motivačním nástrojem pro studenta.

Jedním z cílů těchto zahřívacích aktivit je během několika minut uvolnit atmosféru ve třídě, pokusit se studenty rozmluvit $\mathrm{v}$ cílovém jazyce, prolomit ledy ( $\mathrm{v}$ této počáteční fázi hodiny mohou být tedy warm-up aktivity zároveň ice-breakers, a to tehdy, když u studentů pozorujeme jistý mentální blok, který není jen pouhou „nerozmluveností"). Bývají krátké, rychlé, jednoduché. Tematicky se mohou vztahovat k probíranému učivu, dle našich zkušeností to ale není nutné. Vhodně zvolené zahřívací aktivity mohou udat ráz hodiny a pozitivně ovlivnit její průběh. Přinutí studenty používat češtinu, přepnout do jiného jazykového modu (nezapomínejme, že výuka odborných předmětů v angličtině a kosmopolitní ráz Prahy znamenají, že studenti na začátku hodiny mluví česky po dlouhé pauze, trvající často od konce hodiny minulé - podstatná část studentů od poslední hodiny česky nepromluvila).

\subsection{Warm-up aktivity uprostřed hodiny nebo na jejím konci}

V souladu s tím, co bylo řečeno výše, v průběhu hodiny warm-up aktivity využíváme bud' jako užitečnou př́íprava na určité činnosti (pre-reading activities, prelistening activities), nebo, a to častěji, jako aktivitu sloužící k odlehčení, převedení pozornosti atd. Je-li naším cílem odlehčení, umíst'ujeme je někdy i na konec hodiny. Pobočným cílem v obou případech je též snaha zařadit méně únavný prvek - je známo, že zejména v některých fázích semestru chodí studenti na hodiny češtiny velmi vyčerpaní z teoretických předmětů nebo z mnohahodinového samostudia, a jak nás učí psychologie, změna zaměření mysli je nástrojem proti únavě. 


\subsection{Typy používaných aktivit}

V závěru textu představíme několik konkrétních aktivit, které používáme, nejsou to ale pochopitelně aktivity jediné. Za mnoho let výuky češtiny na lékařských fakultách se podařilo získat či vytvořit výukové materiály, které mohou být základem pro zkoumaný typ aktivit. Máme $\mathrm{k}$ dispozici specializované didaktické a metodologické knihy i on-line materiály (Hádková, Línek \& Vlasáková, 2005, aj.), a i učebnice lékařské češtiny (např. Čermáková, 2018) disponují cvičeními, která mohou sloužit jako warm-up aktivity (např. luštění křížovek, doplňování chybějících písmen, cvičení typu pravda-lež atd., jsou-li zadána jako skupinová nebo párová práce).

Z definice warm-up aktivit vyplývá, že tematicky mohou, ale nemusejí souviset s probíraným učivem, měly by být ale zcela jiného rázu než aktivity, které jim předcházejí, resp. které po nich následují. Ostatně svého druhu warm-up aktivitou je i zcela tradiční neformální rozhovor s žáky, který vede řada učitelů na téma Jaký byl víkend? Jaké máte plány na tento týden? Co tyhle dny děláte? Budete cestovat? Co budete večer dělat?

Jiná tradiční aktivita, během které se zábavným způsobem probíralo téma probíhajících svátků, výročí nebo zrovna aktuálních obyčejů, naráží na potíže spjaté s již zmíněnou kulturní a náboženskou rủznorodostí studentů. Na naší fakultě dříve jednoznačně dominovaly skupiny sestávající z jedné nebo několika málo evropských národností (Norové, Řekové, Portugalci, Španělé), v dnešních skupinách lze pozorovat podstatný podíl studentů z Izraele, Íránu, Saudské Arábie atd. Jelikož našim cílem je účinný vzdělávací proces bez rušivých vlivů, musíme této nové skutečnosti přizpůsobit i volbu témat těchto aktivit. Dříve oblíbené předvánoční a předvelikonoční hodiny zůstávají, nicméně mění se většinou v učitelovu prezentaci o našich tradicích a zvyklostech, tj. pozbývají podoby warm-up aktivity v pravém slova smyslu, protože se už nezpívají společně koledy, nediskutuje se o odlišné podobě oslav Vánoc $\mathrm{v}$ jednotlivých státech a rodinách a podobně. To ale neznamená, že bychom se obecně vyhýbali informacím o historickém, kulturním a společenském životě v naší zemi (pro studenty jsou důležité, když v ČR žijí šest let), jen se mění podoba jejich prezentování.

Naše mnohaletá zkušenost ukazuje, že rozdílný přístup studentů z různých národnostně-kulturních prostředí se odráží i na atmosféře, práci a dynamice výuky v jednotlivých skupinách. Ochota aktivně se zúčastnit warm-up aktivit či např. her je velmi různá. Např již zmiňovaní norští studenti, kteří několikrát do roka sami organizují tzv. pub quizzes, přijímají jakékoli zpestření výuky hrou $s$ nadšením a soutěží velmi urputně. $V$ jiné mnohonárodnostní skupině, která zřejmě sama o sobě není př́liš kompaktní (studenti v ní si nejsou nijak zvlášt' blízcí), může být identická aktivita přijata mnohem chladněji. Jelikož možnou reakci lze 
předem jen těžko odhadnout, snažíme se odlišnosti respektovat a danou aktivitu $\mathrm{v}$ prŕpadě potřeby zkrátíme. Sami jako učitelé vyvíjíme maximální snahu o uvolnění atmosféry ve třídě. Snažíme se studenty velmi podporovat a chválit, dodávat jim sebevědomí $\mathrm{k}$ tomu, aby se snažili mluvit česky, i když jejich jazyková produkce samozřejmě vůbec není bezchybná. Veškeré aktivity monitorujeme a komentujeme, přistupujeme $\mathrm{k}$ nim s odstupem a humorem. Pokud mají někteří studenti zábrany a nechtějí se $\mathrm{z}$ jakéhokoli důvodu aktivně zapojit, nenutíme je $\mathrm{k}$ tomu. Jsme zkrátka smířeni $\mathrm{s}$ tím, že to, co je $\mathrm{s}$ nadšením přijímáno $\mathrm{v}$ jedné skupině, nemusí mít úspěch jinde.

Řada oblíbených warm-up aktivit vyžaduje pochopitelně jistou jazykovou kompetenci. Z důvodů, které jsme již naznačili, je u části našich studentů jazyková vybavenost pro některé $\mathrm{z}$ aktivit nedostatečná, což pochopitelně redukuje portfolio využitelných aktivit.

\subsection{Konkrétní warm-up aktivity}

Na závěr bychom rádi představili sedm warm-up aktivit, které jsou mezi našimi studenty nejoblíbenější (podobných aktivit pochopitelně najdeme mnoho i v dostupné didaktické literatuře, srov. Buttner, 2013). Existují v různých obměnách a každý učitel je může samozřejmě pozměnit s ohledem na konkrétní situaci v dané skupině studentů:

\section{1) Vytváření př́iběhu}

Učitel řekne první slovo a studenti jeden po druhém přidávají další. Učitel píše příběh na tabuli, všichni se společně snaží upravit navržené slovní tvary správně, aby věty dávaly smysl. Nakonec jeden student celý př́běh přečte. Lze různě upravovat; $\mathrm{v}$ jazykově lépe vybavených skupinách může být student vyřazen, pokud slovo neřekne dostatečně rychle, ale většinou je uplatnění tohoto pravidla nemožné.

\section{2) Kufr}

Tato hra, která má též různé podoby, je odvozena od kdysi populární televizní soutěže. Dva dobrovolníci usednou zády k tabuli. Učitel napíše na tabuli pět až sedm slov a zbytek trrídy se snaží česky definovat slova tak, aby je soutěžící co nejdříve uhodl. Student, který uhodne více slov, vyhrává. Jak vyplývá z popisu, tato hra je zaměřena na rozšiřování slovní zásoby a její podoba a plynulost pochopitelně souvisí s jazykovou úrovní skupiny. 


\section{3) Čelovka}

Základem této aktivity je opět hra převzatá z televizního pořadu, je však upravená pro naše podmínky. Dobrovolník si na čelo nasadí čelovou baterku, na kterou učitel připevní jméno známé osoby. Student s čelovkou pokládá ostatním studentům zjištovací otázky (tj. otázky, na které lze odpovědět ano nebo ne) s cílem co nejrychleji uhodnout danou osobu. $\mathrm{V}$ př́padě potřeby je možné studentovi hned na začátku dát jistou indicii jako nápovědu. Vybíráme pochopitelně známé osobnosti mezinárodního kulturního, politického a sportovního života, a to osoby blízké studentskému světu či opravdu univerzálně známé, nicméně úspěchem svého výběru si nemůžeme být jisti nikdy: německá studentka neznala fotbalistu Cristiana Ronalda a norská studentka německou kancléřku Angelu Merkelovou. Hra tak pro nás mj. může být zajímavým svědectvím o dnešním světě.

\section{4) Hádej, kdo jsem}

Jedná se o obměnu předchozí aktivity: dobrovolník si myslí osobu a ostatní studenti mu kladou zjištovací otázky. $V$ případě dlouhého neúspěšného hádání - jež dle našich zkušeností není nijak řídkým jevem - je možné dát studentům nápovědu. Nevýhodou této hry je to, že osobu volí student, takže učitel nemá aktivitu zcela pod kontrolou. Ideální proto je, aby si student svou volbu nechal nejprve učitelem odsouhlasit.

\section{5) Jaký/kdo/co dělá/kde}

Aktivita postavená na tradiční dětské hře. Každý student dostane proužek papíru a na jeho horní část hůlkovým písmem čitelně napíše odpověd’ na otázku JAKÝ? (např. velký, zelený, zkrátka jakékoli adjektivum), papírek přeloží tak, aby napsané slovo nebylo vidět, a pošle dál. Další student napíše na horní okraj nepopsané části odpověd' na otázku KDO?, opět přeloží a zas pošle dál. Postupně studenti odpoví na otázky CO DĚLÁ a KDE? Když jsou všechny otázky zodpovězeny, poslední student papírek rozbalí, opraví př́ípadně gramatiku a větu nahlas přečte. Aktivitu lze použít i ve skupinách s nepř́liš dobrou jazykovou kompetencí, tj. relativně brzy po začátku studia češtiny: důležité je, aby studenti uměli časovat slovesa v př́tomném čase a věděli, co je šestý pád, což je v našich podmínkách na začátku prvního ročníku.

\section{6) Dvě pravdy, jedna lež}

Každý student o sobě napíše dvě pravdy, jednu lež. Např. Každý den běhám. Mám alergii na ryby. Nemám př́telkyni. Ostatní hádají, která informace není pravdivá. Podle našich zkušeností při hře vznikají velmi zábavné situace, které studenty vtahují do jazyka. 


\section{7) Doplnění slov do písničky}

Tato aktivita je velmi oblíbená norskými studenty, kteří jsou velmi často členy pěveckých sborů. Je poměrně obtížná - vyžaduje již celkem pokročilou jazykovou kompetenci. Tato aktivita dle našich zkušeností potvrzuje, že warm-up aktivity mohou být opravdu motivační: řada studentů se snaží do písně proniknout navzdory své nedostatečné jazykové kompetenci. Důležité ale je, aby píseň byla vhodně zvolená (neměla by mít složitý text, měla by být hudebně atraktivní). Mezi našimi studenty jsou oblíbené písně Mezi horami, Vínečko bílé a Sbohem, galánečko.

\section{Závěr}

$\mathrm{V}$ tomto textu jsme chtěli na základě dlouholetých zkušeností $s$ výukou češtiny $\mathrm{v}$ cizojazyčných skupinách na lékařských fakultách ukázat, jakým způsobem a do jaké míry lze $v$ prostředí se zcela specifickou motivací studentů využívat tzv. warm-up aktivity. Jsme přesvědčeni, že právě $\mathrm{v}$ takto neobvyklých didaktických podmínkách představují tyto aktivity nesmírně důležitý nástroj, jehož používání výrazně zlepšuje klima v hodinách a motivaci studentů a přispívá tak $\mathrm{k}$ dosažení základních vzdělávacích cílů.

\section{Literatura}

BetákovÁ, Lucie, Homolová, Eva \& Štulrajterová, Milena (2017). Moderní didaktika anglického jazyka v otázkách a odpovědích. Praha: Wolters Kluwer.

ButTner, Amy (2013). 100 aktivit, her a učebních strategií ve výuce cizích jazyků. Praktické návody, jak zpř́jemnit výuku studentům i sobě. Brno: Edika.

Cullen, BRIAN (1998). Brainstorming Before Speaking Tasks. The Internet TESL Journal. '1998, IV, 7 [online, vid. 21. 10. 2019]. Dostupné z: http://iteslj.org/Techniques/Cullen-Brainstorming/.

ČAPEK, RoBERT (2015). Moderní didaktika. Lexikon hodnotících a výukových metod. Praha: Grada Publishing.

ČErmákovÁ, IVeta (2018). Talking Medicine. Czech for Medical Students. Praha: Nakladatelství Karolinum.

ČERVEnKová, Iva (2013). Výukové metody a organizace vyučování [online, vid. 21. 10. 2019]. Dostupné z http://projekty.osu.cz/svp/opory/pdf-cervenkova-vyukove-metody-a-organizace-vyucovani.pdf.

Fontana, David (2014). Psychologie ve školní praxi: příručka pro učitele. Praha: Portál.

HÁdKovÁ, MARIE, LÍNEK, Josef \& VlasÁKovÁ, Kateřına (2005). Čeština jako cizí jazyk. Úroveň A1. Olomouc: Univerzita Palackého.

JANKovCovÁ, MARIE, PRŮCHA, JIŘí \& KoudelA, JIŘí (1988) Aktivizující metody v pedagogické praxi středních škol, Praha: SNP.

KotrbA, Tomáš \& LACinA, Lubor (2011) Aktivizační metody ve výuce. Brno: Barrister \& Principal.

LOKŠOvÁ, IRENA \& LOKŠA, Jozef (1999). Pozornost, motivace, relaxace a tvořivost dětí ve škole. Praha: Portál.

MAŇÁK, Josef (1990). Nárys didaktiky. 1. vyd. Brno: PdF MU.

MAŇÁK, Josef \& Švec, Vlastimil (2003). Výukové metody, Brno: Paido. 
Marneni, Sagar, Kumar Bondeni, SRavan \& Bhukya, Nagu (2017). The Role of Ice Breakers in English Language Classroom. IJELLH International Journal of English Language \& Literature, V, XI, 2017, 457 až 463.

PetTy, Geoffrey (2013). Moderní vyučování. 6. vyd. Praha: Portál.

RohlíkovÁ, Lucie \& Vejvodová, JANA (2012). Vyučovací metody na vysoké škole, Praha: Grada Publishing.

\section{Autorka}

Mgr. Iveta Čermáková, e-mail: iveta.cermakova@lf3.cuni.cz, zástupkyně přednosty Ústavu jazyků 3. lékařské fakulty Univerzity Karlovy.

Autorka vyučuje češtinu a angličtinu na Ústavu jazyků 3. lékařské fakulty UK. Jejím dlouholetým odborným zájmem jsou praktické a teoretické problémy spjaté s výukou češtiny na lékařských fakultách. Je autorkou učebnice Talking Medicine, která vyšla v několika postupně upravovaných a doplňovaných vydáních, a též spoluautorkou učebnice Slovak for Medical Students, vydané v Bratislavě. 